\title{
Characterization of starch extracted from the roots of Cissus simsiana Roem. \& Schult
}

\author{
Caracterização do amido extraído das raízes da \\ Cissus simsiana Roem. \& Schult
}

\author{
Diego Palmiro Ramirez Ascheri ${ }^{*}$; Cleiber Cintra Morais ${ }^{2}$; Eduardo Ramirez \\ Asquieri ${ }^{3}$; Carlos Wanderlei Piller Carvalho ${ }^{4}$; José Luís Ramírez Ascheri ${ }^{4}$
}

\begin{abstract}
The aim of this study was to investigate the characterization of starch from Cissus simsiana Roem. \& Schult. roots. The starch was extracted by steeping, wet grinding and sedimentation processes and its yield was calculated. Isolated starch was then characterized for chemical composition, morphology and granules size distribution, X-ray diffraction, mid-infrared spectra, swelling powder and solubility, pasting and thermal properties and clarity and syneresis behavior. The starch yield, based on starch presence in the root that can be isolated, were between $13.68 \%$ with $3.1210^{-3} \mathrm{mg} / \mathrm{g}$ of carotenoids. C. simsiana granules were predominantly ellipsoids with 50-60 mm length and 20-30 mm wide. They exhibited B-type X-ray diffraction pattern with $41.2 \%$ of crystallinity, apparent amylose content of $26.2 \%$ and presented similar mid-infrared spectra to other starches. Onset and peak gelatinization temperatures were 64.2 and $68.56^{\circ} \mathrm{C}$, respectively, and gelatinization enthalpy was $19.2 \mathrm{~J} / \mathrm{g}$. The apparent viscosity profile was comparable to cassava starch, but with higher peak viscosity (6500 $\mathrm{cP})$, lower set back viscosity $(600 \mathrm{cP})$ and less clear gel showing syneresis.
\end{abstract}

Key words: Cissus simsiana, rheological properties, thermal properties, X-ray diffraction, mid-infrared spectra, clarity and syneresis

\section{Resumo}

O objetivo do presente estudo foi estudar a caracterização do amido extraído das raízes da Cissus simsiana Roem. \& Schult. A extração do amido foi por via úmida e por decantação, calculando-se seu rendimento. Do amido isolado foram estudados sua composição química, morfologia e distribuição de tamanho dos grânulos, difração de raios-X, espectros no infravermelho médio, poder de inchamento e solubilidade, propriedades de pasta e térmicas, claridade e sinerese. O rendimento de amido, com base na presença de amido na raiz, que pode ser isolado, foi de $13,68 \%$ com $3,1210^{-3} \mathrm{mg} / \mathrm{g}$ de carotenóides. Os grânulos de amido são predominantemente elipsoidais com 50-60 mm de comprimento e 20-30 mm de largura. Exibiram padrão de difração de raios-X tipo B, com 41,2\% de cristalinidade, teor de amilose aparente de $26,2 \%$ e espectros de infravermelho médio semelhante de outros amidos de raízes. As temperaturas de pico de gelatinização inicial e final foram 64,2 e $68,56^{\circ} \mathrm{C}$, respectivamente, e a entalpia de gelatinização foi de 19,2 J/g. O perfil de viscosidade aparente foi semelhante àquele do amido de mandioca, porém, com maior pico de viscosidade $(6500 \mathrm{cP})$, menor tendência à retrogradação $(600 \mathrm{cP})$ e com géis menos claros mostrando sinerese. Cissus simsiana raízes tem uso potencial para a produção

\footnotetext{
${ }^{1}$ Prof. da Universidade Estadual de Goiás, UEG, Anápolis, GO, Brasil. E-mail: ascheridpr@gmail.com

${ }^{2}$ Discente, UEG, Anápolis, GO, Brasil. E-mail: cleibermorais@hotmail.com

${ }^{3}$ Prof. da Universidade Federal de Goiás, UFG, Goiânia. GO, Brasil. E-mail: asquieri@gmail.com

${ }^{4}$ Pesquisadores da Embrapa Agroindústria de Alimentos, Guaratiba, RJ, Brasil. E-mail: ascheri@ctaa.embrapa.br; cwpiler@ctaa. embrapa.br

* Author for correspondence
} 
de amido e há espaço para aumentar o seu rendimento. Cissus simsiana amidos tem um grânulo de tamanho médio de fécula de batata com clara tipo B padrão de difração de raios-X, típico de tubérculos com arranjo de cadeias moleculares diferentes de amidos de cereais. Cissus simsiana amidos tinham temperaturas e entalpias de gelatinização semelhantes a mandioca e outros amidos isolados a partir de fontes não-convencionais, que podem ser interessantes para a possível utilização como uma alternativa tecnológica em algumas aplicações industriais.

Palavras-chave: Cissus simsiana, propriedades reológicas, propriedades térmicas, difração de raios X, espectro no infravermelho, claridade e sinerese

\section{Introduction}

The conventional starch sources, corn and cassava, are widely used for different industries such as food, petroleum, textile and metallurgy. The demand for starch and specialty starches is increasing as a result of new technologies and consumption growth. As a consequence, the study of alternative starch sources has been considered for attending this new scenario.

Starch is the source of energy reserve of vegetables present in cereals, tubers and roots. It is a carbohydrate consisting of two macromolecules: amylopectin and amylose formed by glucose units joined together by glycosidic a(1"4) linkages. Amylose is essentially linear and amylopectin is highly branched presenting glycosidic a(1"6) linkages (TESTER; KARKALAS; QI, 2004). In food products, starch molecules are used to modify and control various characteristics, such as texture, appearance, moisture, consistency and shelf life stability, which are controlled by physico-chemical and functional properties of starches. Those properties are influenced by the botanical source that originated the granular and molecular structures of starch (SINGH et al., 2003).

The most important functional properties of starch for food applications are granular size and shape, gel transparency and opacity, gelatinization and retrogradation, solubility, swelling, water absorption, syneresis and paste viscosity (HERNÁNDEZ-MEDINA et al., 2008).

The gelling properties are related to several factors, including proportions of amylose and amylopectin, type of crystallinity, size and structure of the starch granule (TESTER; MORRISON, 1990).

The crystalline region of starch is mainly composed by the branched amylopectin molecules whereas amylose is dispersed within the amorphous region (PARKER; RING, 2001). Therefore, the crystallinity of the starch granules is measured by $x$-ray diffraction given by the presence of the aligned and compacted double helices formed by the branched amylopectin (HOOVER, 2001).

Hernández-Medina et al. (2008) reported that during the gelatinization process, which requires a combination of excess of water, heat and shearing, the molecular order among the starch granules is destroyed gradually and irreversibly.

Paste viscosity is one of the most important properties of starchy materials. The viscosity curve represents the behavior during heating and allows evaluating the characteristics of the paste formed due to structural modifications of starch molecules and retrogradation during cooling and storage. Starch retrogradation includes short term retrogradation mainly by amylose and long term retrogradation by amylopectin (ZHOU; LIM, 2012).

The Brazilian savannah biome is one of the richest biodiversity in number of vegetable species of the world. There is still starch sources that has not been studied that could present properties for potential uses. C. simsiana Roem. \& Schult (Vitaceae) produces a tuberous root that contains starch. In the Brazilian city of Burí (SP, Brasil) it is known as varied names, such us "uva do mato de cinco folhas"," "uva roxa do mato" or "uva folha de ipê" and Bariri (LOMBARDI, 2013), whereas in 
Itapuranga city (GO, Brasil) it receives other name "parreira do mato". The local farms report that during drying season, the roots are used for cattle feeding and its starch is also used for medicinal purpose, but there is no consistent information of extraction yield and physical properties, therefore the aim of this work was to provide these knowledge.

\section{Material and Methods}

\section{Starch yield and chemical composition}

The roots of healthy plants of $C$. simsiana Roem. $\&$ Schult. were collected in the vicinity of the city of Itapuranga (GO, Brazil), located at $651 \mathrm{~m}$ above sea level at coordinates: $15^{\circ} 33^{\prime} 44^{\prime \prime}$ South latitude and 4956'55" West longitude.

The experiment was conducted in a completely randomized design. The roots harvested (approximately $40 \mathrm{~kg}$ ) were washed in running water, fresh cut and transported in polyethylene bags to minimize moisture losses.

The methodology used for isolating the starch from the roots was described by Ascheri et al. (2010). The reddish peel surrounding the roots was manually removed. The peeled roots were chopped and stored in plastic containers containing sodium metabisulphite $(5 \mathrm{~g} / \mathrm{L})$ in a proportion of $1 \mathrm{~kg}$ of roots for $2 \mathrm{~L}$ of metabisulfite solution $(1: 2, \mathrm{w} / \mathrm{v})$ for $15 \mathrm{~min}$. The wet grinding was carried out on an industrial blender LQ 25 (Metvisa, Brusque, Brazil), obtaining a dough like material, which was sieved with a polyester cloth and successively washed with water, to separate the starch by decantation in plastic containers. The starch was decanted, filtered and then dried under vacuum at $40^{\circ} \mathrm{C}$ for $12 \mathrm{~h}$. The dehydrated starch remained 3 $\mathrm{h}$ in a desiccator containing silica gel and then was reduced to powder using a mortar and pestle and then sieved on a sieve of $180 \mu \mathrm{m}$ aperture obtaining a powder for further analysis.

The yield of $C$. simsiana Roem. \& Schult. starch (CSS) was calculated according to Equation (1), from decorticated roots.
Starch yield $(\%)=\frac{\text { Mass of dry starch sample after extraction }(\mathrm{db})}{\text { Mass of shelled roots }(\mathrm{wb})} \times 100(1)$

The official methods of Association of Official Analytical Chemists (1990) were used to determine moisture (925.09), protein (979.09), lipid (923.05), crude fiber (962.09) and ash (923.03) contents of the starch powder. Quantitative estimation of apparent amylose and total carotenoid were determined according to the methodology described by Rincón and Padilla (2004) and Higby (1962), respectively.

Optical and scanning electron microscopy and particle size distributions.

Microphotography of CSS was carried out on the scanning electron microscope TM 3000 (Hitachi, Tokyo, Japan) at $15 \mathrm{kV}$ acceleration and magnification from 1000 to $2500 x$. The sample was left in the desiccator with silica gel drying for 24 $h$, loaded on a double-sided adhesive carbon tape attached to the aluminum support and then taken directly to the microscope of low vacuum chamber.

Granule size distribution was determined by using an image analysis Leica LAS EZ (Wetzlar, Germany) directly recorded in the Leica DM E microscope (Wetzlar, Germany). Starch samples were suspended in distilled water to provide a sharper image of the granules and analyzed by Leica Application Suite LAS EZ v. 2.0.0 software (Wetzlar, Germany). The analysis was performed in 90 granules of starch.

\section{$X$-ray diffraction and mid-infrared spectra}

Powder X-ray diffraction pattern was obtained by using a wide angle Rigaku RU-200 X-ray diffractometer (Rigaku, Osaka, Japan). The powder was scanned using $\mathrm{Cu}$ Ka radiation $(\mathrm{k}=1.54056 \AA)$ at $40 \mathrm{kV}$ and $150 \mathrm{~mA}$. The angles of the scanning region (2q) were from 5 to $40^{\circ}$ at a scanning speed of $0.2 \% \mathrm{~min}$. The scan steps size of 0.02 were used with a dwell time of $0.2 \mathrm{~s}$. The degree of crystallinity of samples was quantitatively estimated following the 
method of Nara and Komiya (1983). Besause X-ray intensity of starch is affected by moisture content, samples were conditioned at $75 \%$ rh for three days before taking the X-ray diffraction patterns.

The mid-infrared spectra (4000 to $400 \mathrm{~cm}^{-1}$ at $1 \mathrm{~cm}^{-1}$ data intervals) of the starch sample was collected with a spectral resolution of $4 \mathrm{~cm}^{-1}$ on a Perkin-Elmer Spectrum Frontier FTIR/NIR spectrometer (Perkin-Elmer Corp., Norwalk, CT, USA). The spectrophotometer was fitted with a wire coil operated at $1350 \mathrm{~K}$ the IR light source, a potassium bromide beam splitter and equipped with a deuterated tryglycine sulfate (DTGS).

\section{Paste viscosity and thermal properties}

The Rapid Visco Analyser (RVA 4, Newport Scientific PTY, Warriewood, Australia) was used to measure the apparent viscosity of samples following the standard method described in the manual of the equipment. A starch sample $(10 \% \mathrm{w} / \mathrm{w}$, dry weight basis) was subjected to the following heating and cooling programmer: equilibrated at $50^{\circ} \mathrm{C}$ for $1 \mathrm{~min}$, heated at $12^{\circ} \mathrm{C} / \mathrm{min}$ to $95^{\circ} \mathrm{C}$, held at $95^{\circ} \mathrm{C}$ for 2.7 min, cooled at same rate to $50^{\circ} \mathrm{C}$, and held at $50^{\circ} \mathrm{C}$ for $2 \mathrm{~min}$. The paste viscosity readings were: peak viscosity ( $\mathrm{PV}$, maximum viscosity during heating), breakdown (BD, the difference between peak viscosity and the hot paste viscosity) and setback (SB, the difference between maximum viscosity during cooling and the hot paste viscosity). The pasting profiles were evaluated in triplicate and the average values of evaluated pasting parameters were reported.

The thermal analysis of starch was obtained using a differential scanning calorimeter (DSC Q200, TA Instruments, New Castle, USA). 2-3 mg of starch with known water content were transferred to an aluminum hermetic pan in excess of water (at least 2 times the mass of solids). These pans were hermetically sealed, left overnight at room temperature and heated from 5 to $110{ }^{\circ} \mathrm{C}$ at $10{ }^{\circ} \mathrm{C} /$ min. The melting enthalpy and the temperature were calibrated with indium. The enthalpy and temperatures of gelatinization were calculated using the Universal Analysis software version 4.3A (TA Instruments, New Castle, USA). The analysis was performed in duplicate.

\section{Swelling power (g/g) and solubility (\%)}

Swelling power (SP) and water solubility index (SI) were determined using the methodology described by Leach, McCowen and Schoch (1959) with modifications. In order to determine the swelling power, a starch sample ( $0.2 \mathrm{~g}$, dry basis) was weighed accurately in a centrifuge tube before $10 \mathrm{ml}$ of distilled water were added. The slurry was heated at $30-90^{\circ} \mathrm{C}$ in a water bath for $30 \mathrm{~min}$. Subsequently, after samples were cooled to room temperature, the solution was centrifuged at $3000 \mathrm{~g}$ for $15 \mathrm{~min}$. The supernatant obtained was carefully removed, and the swollen starch sediment was weighed. The aliquot of supernatant was evaporated overnight $\left(100^{\circ} \mathrm{C}\right)$. Analyses were performed in triplicate. Swelling power and solubility were calculated as follows:

Swelling power $(\mathrm{g} / \mathrm{g})=\frac{\text { Weight of the wet sediment }(\mathrm{g})}{\text { Weight of the dry } \operatorname{starch}(\mathrm{g})}$

Solubility $(\%)=\frac{\text { Weight of dried supernantant }(\mathrm{g})}{\text { Weight of the dry starch }(\mathrm{g})} \times 100$

\section{Light transmittance and syneresis}

The procedures of Craig et al. (1989) were used to determine light transmittance of the gels, modified. An aqueous suspension of starch ( $1 \%$, in dry basis) was heated in a water bath at $90^{\circ} \mathrm{C}$ for $1 \mathrm{~h}$ with constant stirring, transferred to plastic tubes and stored for four days at $4^{\circ} \mathrm{C}$ in a refrigerator. The sample was then stored for 4 days at $4^{\circ} \mathrm{C}$ in a refrigerator and transmittance was measured after every $24 \mathrm{~h}$ at $640 \mathrm{~nm}$ using the UV-Vis spectrophotometer SP-2000 UV. Aqueous suspensions of starch $(5 \%, \mathrm{w} / \mathrm{w})$ were shaken for 
$30 \mathrm{~min}$ at room temperature, then were heated in a boiling water bath (30 min) with constant stirring. Immediately $1 \mathrm{~g}$ of starch slurry was dispensed into tubes. The gel obtained was placed in the refrigerator for four days at $4^{\circ} \mathrm{C}$. Syneresis was measured as the percentage (in dry basis) of water released after centrifugation at $3.200 \times \mathrm{g}$ for $15 \mathrm{~min}$. Every 24 $\mathrm{h}$ the exuded water was measured. Analyses were performed in triplicate.

\section{Statistical analysis}

The data of granule size distribution were analysed by frequency analysis with significance at $p<0.05$. Other data were described by means. The statistical analyses were conducted using Statistica 8.0 (StatSoft, Tulsa, USA).

\section{Results and Discussion}

Plant characterization, starch yield and chemical composition

The plant of C. simsiana, which is small shrub commonly known as bush vine displays creeping habits in an open field, is shown in Figure 1A. Their roots present tubular shape with smooth surfaces (Figure 1B and 1C) and contain $86.7 \%$ water and may reach $1.0 \mathrm{~m}$ in length and $0.3 \mathrm{~m}$ in diameter weighing up to $4 \mathrm{~kg}$. The color of the peel of the young roots varies from light yellow to orange, and when an adult exhibit intense red color (Figure 1C).

To contain high water and fibrous material, the root of $C$. sinsiana present low yield of starch (13.68\%, wet basis) when compared to cassava (21-33\%, wet basis) (MENDONÇA; MOURA; CUNHA, 2003). The starch presented cream color, which was due to the presence of carotenoids (3.12 $\left.10^{-3} \mathrm{mg} / \mathrm{g}\right)$. CSS showed low ash content $(0.41 \%)$, protein $(0.11 \%)$, crude fiber $(0.15 \%)$ and considerable phosphorus content $(0.02 \%)$, absence of lipids and moisture content of $9.52 \%$.

Figure 1. A) Cissus simsiana Roem. \& Schult. plant (bush vine), B) roots showing the shape and size, and C) roots after washing (note the redish color). Source: Author own (2012).
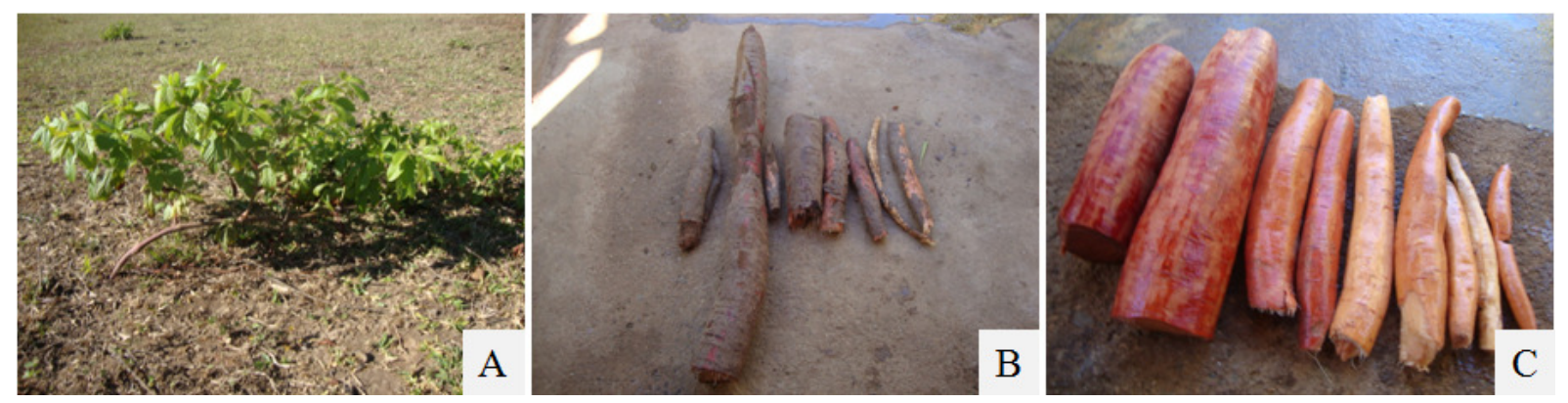

Source: Elaboration of the authors.

Amylose content varies according to the origin and plant maturity and its determination can be affected by the type of methodology and sample preparation as well as by the length of lateral chains (if they are too long can also absorb iodine and overestimate amylose content) (VILAPLANA;
HASJIM; GILBERT, 2012). CSS showed 26.6\% of amylose, similar to the amylose content of potato, 15-31.0\% (KAUR et al., 2007b; KIM et al., 1996; NADIHA et al., 2010; SINGH et al., 2003), however it was higher than cassava, 16.7-18.6\% (HOOVER, 2001; MOORE et al., 2005). 
As for amylose, phosphorous content also affects the starch functionality such as paste viscosity. In potato starch, it has been found phosphorus content in a range of 0.05 to $0.1 \%$ (KIM et al., 1996; SINGH et al., 2003; SRICHUWONG et al., 2005; KARIM et al., 2007) and in cassava starch the range was slight low from 0.01 to $0.03 \%$ (SRICHUWONG et al., 2005; OLUDARE; MACDONALD, 2010). CSS showed similar phosphorous content to cassava starch, which was $0.02 \%$.

Scanning electron microscopy and particle size distribution

According to Singh et al. (2003), morphological characteristics of starches from different plant sources vary with the genotype and cultural practices. The granule size is variable and ranges from 1 to 110 $\mathrm{mm}$ (HOOVER, 2001). The average granule size ranges from 1 to $20 \mathrm{~mm}$ for small and 20 to $110 \mathrm{~mm}$ for large potato starch granules. The granules of CSS (Figure 2A-D) showed predominantly ellipsoidal and irregular shape of smooth surface measuring between 20-140 mm length (Figure 2E) and 15-55 $\mathrm{mm}$ width (Figure 2F), approximately. The particle size distribution displayed in Figure 2 shows that the average length is around $60 \mu \mathrm{m}$ whereas average width is $25 \mu \mathrm{m}$, which is an evidence of the predominance of ellipsoid shape. Alvani et al. (2011) extracted starch from ten potato cultivars grown under the same conditions and found varied starch sizes and shapes. Size varied from 5 to 100 $\mu \mathrm{m}$, but the average mean diameter was $25.8 \mu \mathrm{m}$ with predominately ellipsoidal and oval shape.
According to these results, the morphology and size of CSS granules were similar to native potato starch, since the size of CSS starch was considered higher than the other starch sources.

\section{Infrared spectra and X-ray diffraction}

Since starch is constituted of amylose, amylopectin and water, it was expected the spectral bands showed in Figure 3A. Generally, the hydroxyl groups present on the D-glucose unit of starches from different botanical sources appear as a broad band rounded in a wavelength region between 3900-3300 $\mathrm{cm}^{-1}$ (WANG et al., 2009). In the case of CSS, the spectral band was slight narrow (width at half height of $475 \mathrm{~cm}^{-1}$ ) valued wave number of maximum absorption at $3453.04 \mathrm{~cm}^{-1}$. The peaks that characterize the ring of links $\mathrm{C}-\mathrm{H}$ stretch and $\mathrm{C}$-glycosidic linkage present values of wave number at maximum absorption of 2930.12 and 1643.12 $\mathrm{cm}^{-1}$, respectively, similar to the values found by Nakason et al. (2010) and Wang et al. (2009) for C-H, which ranged from 2923 to $2926 \mathrm{~cm}^{-1}$, when working with cassava and corn, respectively. The spectral bands of maximum absorbance of 1162.74 , 1080.49 and $1007.50 \mathrm{~cm}^{-1}$ indicated the presence of the links C-O-C. Nakason et al. (2010), studying cassava starch, also detected these peaks in the spectral bands of maximum absorbance of 1156 , 1051 and $1023 \mathrm{~cm}^{-1}$, respectively. 
Figure 2. Micrographs of starch granules extracted from the roots of Cissus simsiana Roem. \& Schult.: A) 500x, B) and C) 2000x, and D) 2500x. Granule size distribution: E) length, and F) width.
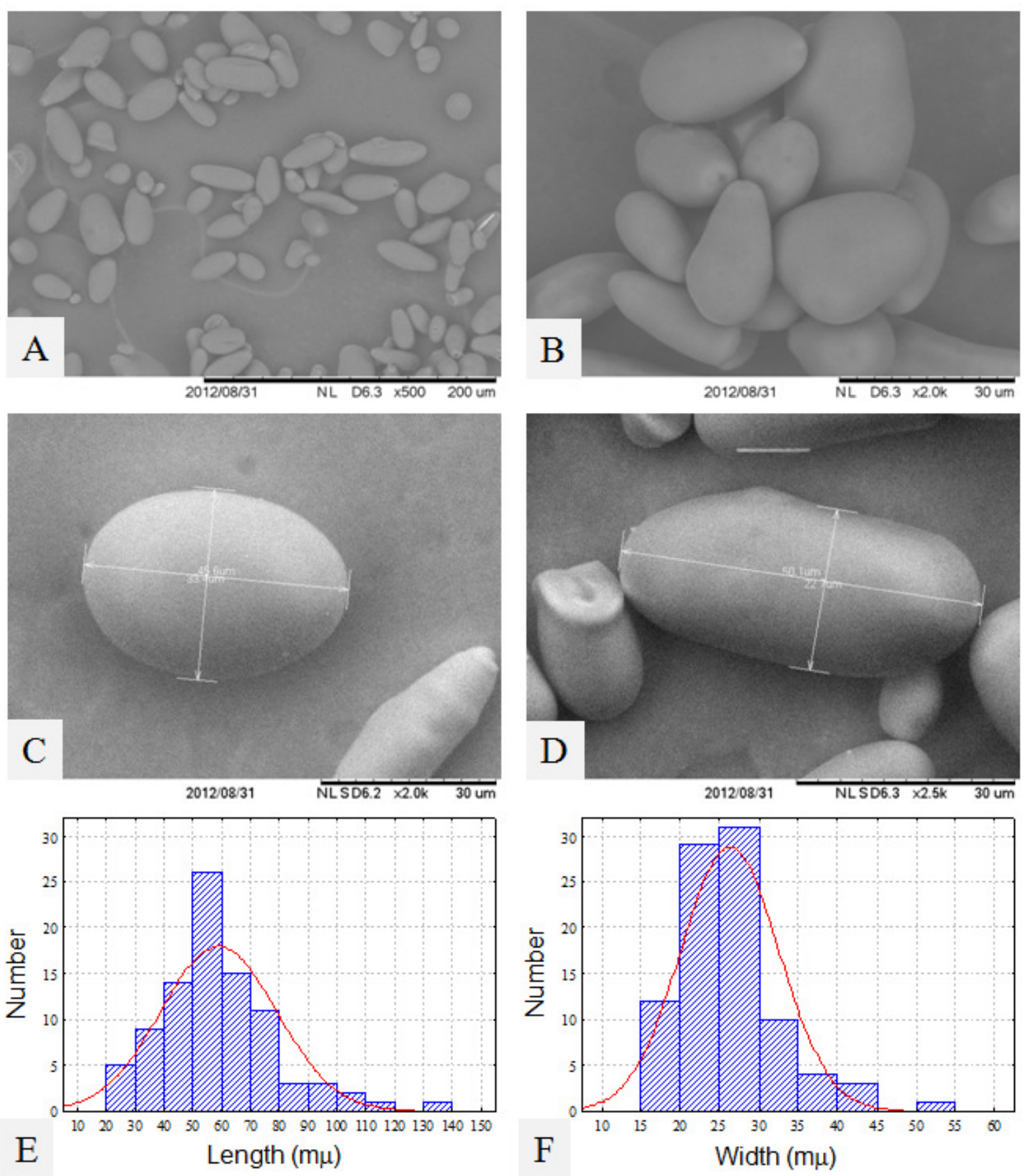

Source: Elaboration of the authors. 
Figure 3. A) The infrared spectrum obtained by the $\mathrm{KBr}$ pellet transmission and $\mathrm{B}$ ) X-ray diffractogram of the starch extracted from the roots of Cissus simsiana Roem. \& Schult.

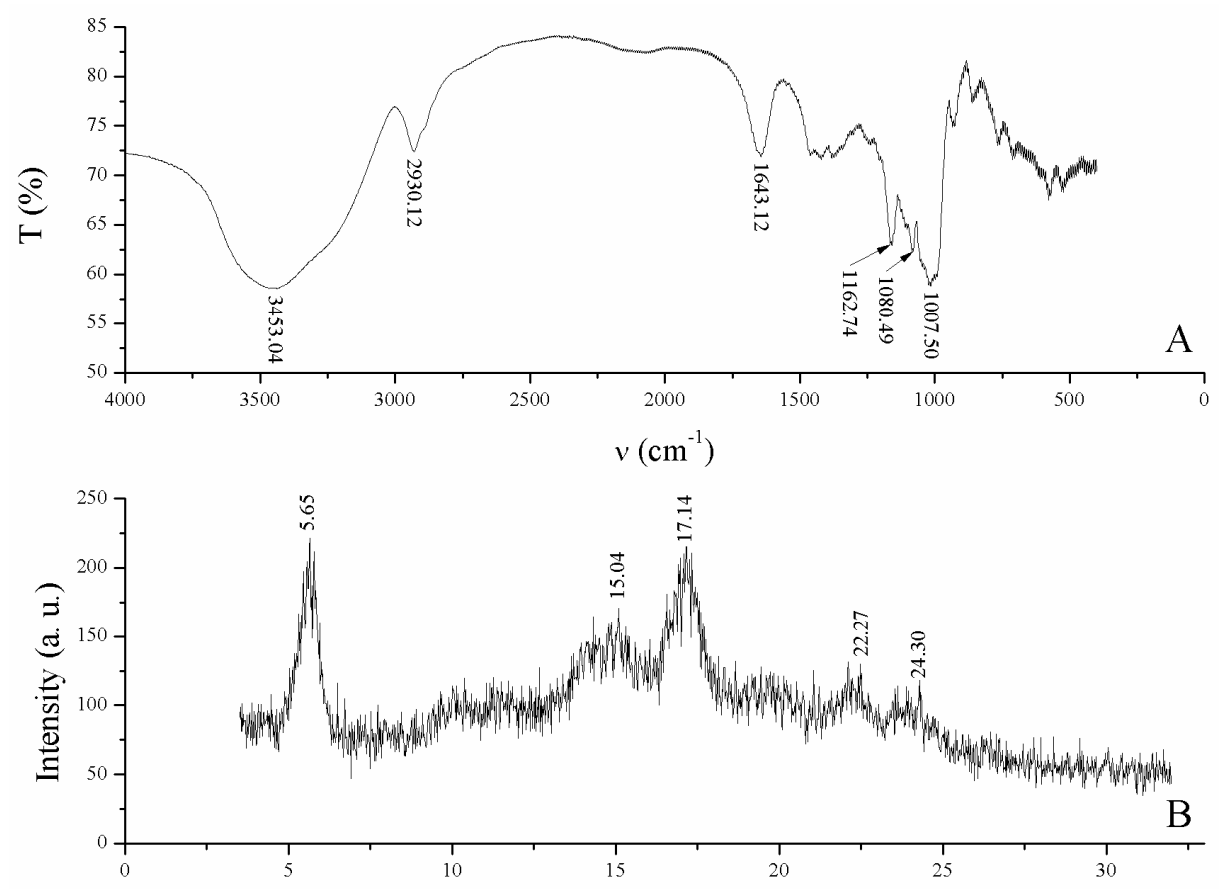

Source: Elaboration of the authors.

According to Parker and Ring (2001) the starch granules are arranged in crystalline and amorphous regions, being the gradual transition between them. The crystalline region is mainly composed of side chains of amylopectin, while the branch points and amylose are the main components of amorphous regions. According to their crystallinity, the starch granules show, through X-ray diffraction, various forms of double helices packaging of amylopectin, denominated A, B or C crystal types. According to Leonel et al. (2002), B crystal type presents peaks of high intensity at 5.6, 15, 17, 22 and $23^{\circ}$ (2q), characteristic of tuber starches. In the case of CSS, the diffractogram pattern (Figure 3B) showed peaks at $5.69,15.04,17.14,22.27$ and $24.30^{\circ}(2 \mathrm{q})$, indicating a B type crystal arrangement (typical of potato starch), with $41,2 \%$ of crystallinity.

\section{Pasting properties and differential scanning calorimetry}

The paste viscosity profile of the starch slurry extracted from the roots of $C$. simsiana is displayed in Figure 4A. The paste formation of CSS occurred after $2.5 \mathrm{~min}$ of constant stirring at temperature of $68^{\circ} \mathrm{C}$. CSS showed higher pasting temperature than potato starch $\left(\sim 66.8^{\circ} \mathrm{C}\right)$ (KAUR et al., 2007a), which could be attributed to its high amylose content when compared to potato starch and also to the type A crystal found in CSS starch granules, which differs to potato starch $\mathrm{B}$ type observed by $\mathrm{x}$-ray diffraction. After $68^{\circ} \mathrm{C}$, a steep rise in viscosity was observed reaching $6500 \mathrm{cP}$ (PV). A narrow peak width indicated that the binding forces of the structure of the granules were relatively weak, i.e., most granular structure was broken at the occurrence of the maximum peak viscosity, where it is observed a prevalence of granular collapse over starch swelling, also observed in potato (ALVANI et al., 2011) and cassava starches (OLUDARE; MACDONALD, 2010). 
Figure 4. A) Apparent paste viscosity curve and B) DSC thermogram of the starch extracted from the roots of Cissus simsiana Roem. \& Schult.

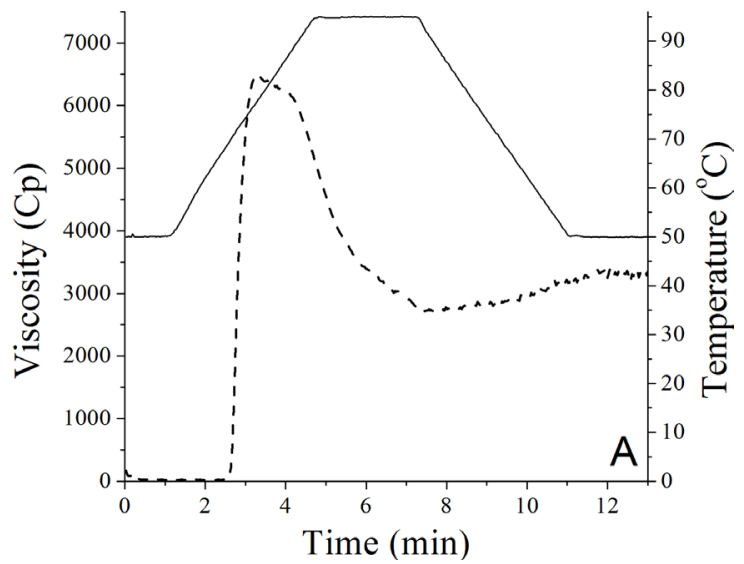

Source: Elaboration of the authors.

It has been reported that low swelling factor and stronger crystalline structure (A type crystals with high proportion of $\mathrm{B} 1$ chains) cause a low peak viscosity in starch (CHUNG et al., 2008), which is prevalent in cereal starches. In contrast, cassava starch (BAHNASSEY; BREENE, 1994), due to the low levels of amylose to reinforce the molecular network within the granules, demonstrated high peak viscosities with consequent great breakdown and narrow peak width similar to CSS starch.

According Kaur et al. (2007a) starch granules become increasingly susceptible to shear disintegration as they swell, and starches with low amylose content swell more than those with higher amylose content. Besides, high retrogradation tendency is typical of starches with high amylose by the ease re-association of molecule starch gel, when subjected to cooling. In the present study, although the amylose of CSS was relatively high, the breakdown viscosity was $3800 \mathrm{cP}$ (with minimum viscosity value of $2700 \mathrm{cP}$ ) within the heating cycle, which shows low stability as a result of weak forces maintaining the integrity of the starch granules. However, during the cooling cycle, the viscosity increased to $600 \mathrm{cP}$ (retrogradation tendency), reaching the final viscosity of $3300 \mathrm{cP}$, which was low, may be attributed to the high crystallinity of

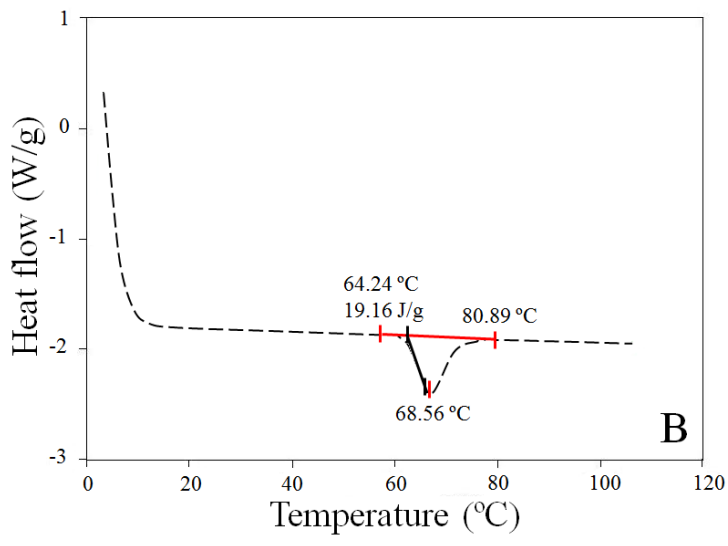

CSS. The low retrogradation gel recover may indicate low tendency to syneresis, as observed to normal starch gel when subjected to cooling.

As for paste viscosity readings, CSS showed similar paste behavior to cassava starch, i.e. rapid formation of the viscosity peak followed by a sharp drop in viscosity with low tendency to retrogradation. However CSS showed higher peak viscosity value, at least two fold the paste viscosity of cassava starch and lower retrogradation tendency when compared to the work of Zaidul et al. (2007), which found $1618.8 \mathrm{cP}$ of peak viscosity and $559 \mathrm{cP}$ for setback or retrogradation viscosity.

The gelatinization enthalpy values of starches have been reported to be affected by granule shape, percentage of large and small granules and the presence of phosphate esters (SANDHU; SINGH; KAUR, 2004). The value of the enthalpy of CSS was $19.16 \mathrm{~J} / \mathrm{g}$, considerably higher than cassava $(14.13 \mathrm{~J} / \mathrm{g})$ (FRANCO et al., 2010) and potato (10-18 J/g) (KAUR et al., 2007a; NADIHA et al., 2010), but similar to corn (19.92 J/g) (BENINCA et al., 2008), demonstrating that CSS requires more energy to break the crystalline region of the starch granules than cassava and potato starch, but similar 
to corn starch, a cereal starch with A type crystal conformation. The high gelatinization enthalpy value of CSS would be attributed to its great granule size, high amylose content and considerable phosphate content. Also, the CSS might contain high proportions of the longer chains in the amylopectin, which could form long double helices that would require a higher energy to dissociate completely than that required for shorter double helices (YUAN; THOMPSON; BOYER, 1993).

\section{Swelling power $(g / g)$ and solubility (\%)}

The swelling power (SP) and water solubility index (SI) of CSS are displayed in Figure 5A. According to Leach, McCowen and Schoch (1959) usually solubility and swelling power are correlated. However, it was observed that SP showed a more pronounced increase after reaching $50^{\circ} \mathrm{C}$ until $70^{\circ} \mathrm{C}$, coinciding with the initial paste viscosity of RVA curve. The maximum value of SI was $11.46 \%$ at $90^{\circ} \mathrm{C}$, which was higher than those of cassava starch $\left(3.2 \%\right.$ to $\left.89^{\circ} \mathrm{C}\right)$, determined by Uthumporn, Zaidul and Karim (2010).

Figure 5. A) Swelling power and solubility index and B) Turbidity and syneresis of starch extracted from the roots of Cissus simsiana Roem. \& Schult.
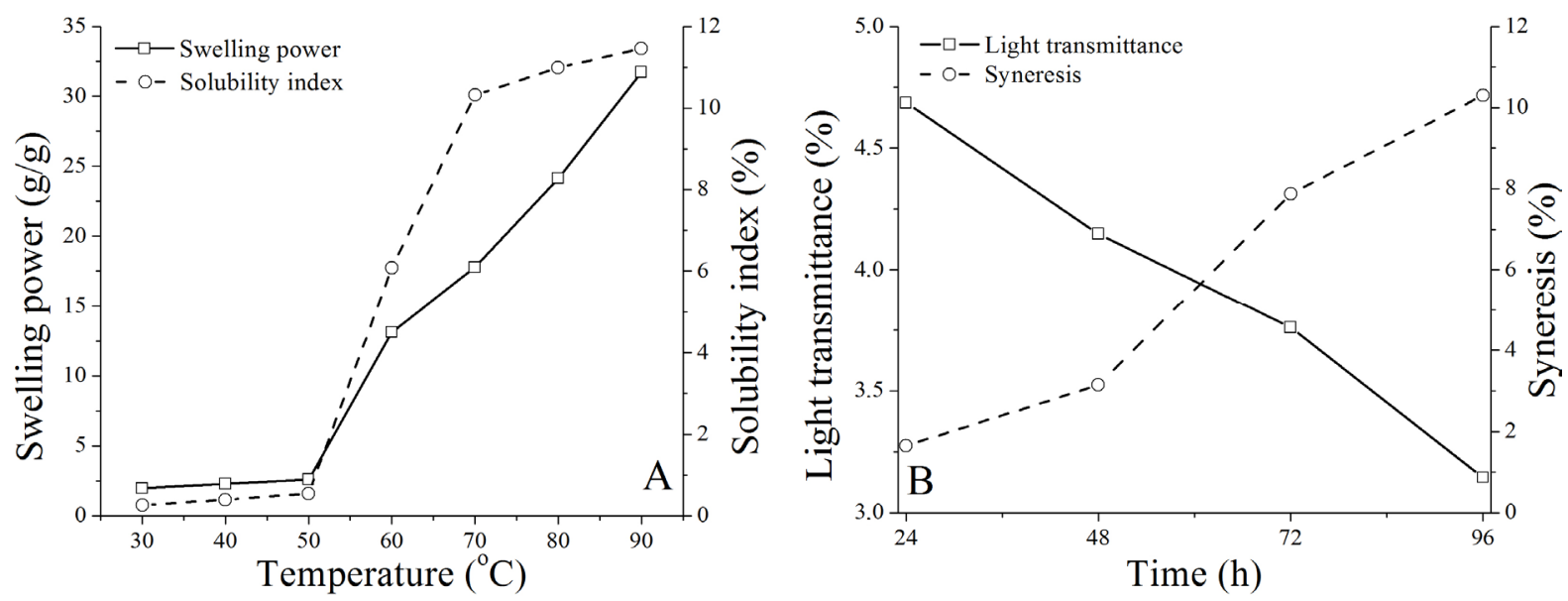

Source: Elaboration of the authors.

As showed by Moore et al. (2005) for cassava starch, swelling power and water solubility index increase with temperature. According to Singh et al. (2003), when the starch granules are heated in excess water, the crystalline structure of the starch granule is disrupted, and the water molecules form hydrogen bonds with amylose and amylopectin, thus increasing the solubility and the swelling of the starch granule. From $50^{\circ} \mathrm{C}$ the value of SP rapidly increased, suggesting the onset of formation of the paste produced by CSS. This phenomenon reinforces the rapid and high increase of paste formation, which could be also seem in the RVA paste curve, i.e. the granules of CSS have poor structural internal strength, since the initial paste viscosity was observed at relative low temperature. Also, this might be attributed to the high crystallinity and size granules of CSS, as the value of SP at $90^{\circ} \mathrm{C}$ was $31.72 \mathrm{~g} / \mathrm{g}$, which was higher than corn $(13.9 \mathrm{~g} / \mathrm{g}$ at $\left.95{ }^{\circ} \mathrm{C}\right)$ and cassava starches $\left(18.9 \mathrm{~g} / \mathrm{g}\right.$ at $\left.89^{\circ} \mathrm{C}\right)$ (UTHUMPORN; ZAIDUL; KARIM, 2010).

\section{Light transmittance and syneresis}

The light transmittance of the CSS gel decreased from $4.7 \%$ to $3.1 \%$ after 4 days stored at $4^{\circ} \mathrm{C}$, which 
represented a third of light transmittance reduction. In the same time and temperature storage condition, Craig et al. (1989) determined the light transmittance at $650 \mathrm{~nm}$ of potato starch, cassava, wheat and corn gels, obtaining $9.6,6.2,3.9$ and 2.9, respectively, whereas Kaur et al. (2007a) analyzing the gels of 21 different Indian potato cultivars, they obtained the average light transmittance values of 16.9 (first day) and $13.4 \%$ (fourth day). This indicates that gel CSS presented transmittance between cassava and corn gels, which was far lower than potato starch. The low light transmittance exhibited by CSS may be due to high refraction of light by swollen starch granule remnants (CRAIG et al., 1989). Granule swelling, granule remnants, leached amylose and amylopectin and the molecular weights and chain-lengths of amylose and amylopectin have been reported to vary with granule size, which ultimately leads to the development of turbidity and decreased light transmittance in starch pastes during refrigerated storage (PERERA; HOOVER, 1999; KAUR et al., 2007a). The low light transmittance of CSS gels can be easily correlated to the considerable amylose molecules present in the CSS starch granules.

According to Zhang, Tong and Ren (2012) the exudation of water is due to the reassociation of starch molecules, particularly amylose, that form ordered structure leading to retrogradation viscosity. As the CSS gels in the first day of storage lost $11.5 \%$ water, stabilizing on the fourth day at $4{ }^{\circ} \mathrm{C}$ and achieving a total water loss of $32.9 \%$, it showed strong effect of amylose reordering. This information indicates that CSS starch would not be suitable for using in chilled foods, contrary to what happens with cassava starch as well as for waxy maize starch, when the water loss can be as low as 0 and $9 \%$, respectively (TAKIZAWA et al., 2004).

\section{Conclusions}

Cissus simsiana Roem. \& Schult roots has potential use for starch production and there is room for increasing its yield. C. simsiana starches have a medium size granule than potato starch with clear B type X-ray diffraction pattern, typical from tubers with molecular arrangement chains different from cereal starches. C. simsiana starches had temperatures and enthalpies of gelatinization similar to cassava and other starches isolated from nonconventional sources, which could be interesting for possible use as a technological alternative in some industrial applications.

\section{Acknowledgments}

Thanks to Fapeg, Pibic/UEG and CNPq for their financial support.

\section{References}

ALVANI, K.; QI, X.; TESTER, R. F.; SNAPE, C. E. Physico-chemical properties of potato starches. Food Chemistry, Saint Paul, v. 125, n. 3, p. 958-965, 2011.

ASCHERI, D. P. R.; MOURA, W. S.; ASCHERI, J. L. R.; CARVALHO, C. W. P. Caracterização física e físico-química dos rizomas e do amido do lírio-dobrejo (Hedychium coronarium). Pesquisa Agropecuária Tropical, Goiânia, v. 4, n. 2, p. 159-166, 2010.

ASSOCIATION OF OFFICIAL ANALYTICAL CHEMISTS - AOAC. Official methods of analysis. 15. ed. Arlington: AOAC International. 1990. 140 p.

BAHNASSEY, Y. A.; BREENE, W. M. Rapid ViscoAnalyzer (RVA) pasting properties of wheat, corn, waxy corn, tapioca and amaranth starches (A. hypochondriacus and $A$. cruentus) in the presence of konjac flour, gellan, guar, xanthan and locust bean gums. Starch/Stärke, Weinheim, v. 4, n. 4, p. 134-141, 1994.

BENINCA, C.; DEMIATE, I. M.; LACERDA, L. G.; FILHO, M. A. S. C.; IONASHIRO, M.; SCHNITZLER, E. Thermal behavior of corn starch granules modified by acid treatment at 30 and $50^{\circ} \mathrm{C}$. Eclética Química, São Paulo, v. 33, n. 3, p. 13-18, 2008.

CHUNG, H. J.; LIU, Q.; DONNER, E.; HOOVER, R.; WARKENTIN, T. D.; VANDENBERG, B. Composition, molecular structure, properties, and in vitro digestibility of starches from newly released Canadian pulse cultivars. Cereal Chemistry, Saint Paul, v. 85, n. 4, p. 471-479, 2008. 
CRAIG, S. A. S.; MAINNGAT, C. C.; SEIB, P. A.; HOSENET, R. C. Starch paste clarity. Cereal Chemistry, Saint Paul, v. 66, n. 3, p. 173-182, 1989.

FRANCO, C. M. L.; OGAWA, C.; RABACHINI, T.; ROCHA, T. S.; CEREDA, M. P.; JANE, J. L. Effect of lactic acid and UV irradiation on the cassava and corn starches. Brazilian Archives of Biology and Technology, São Paulo, v. 53, n. 2, p. 443-454, 2010.

HERNÁNDEZ-MEDINA, M.; TORRUCO-UCO, J. G.; CHEL-GUERRERO, L.; BETANCUR-ANCONA, D. Caracterización fisicoquímica de almidones de tubérculos cultivados en Yucatán, México. Ciência e Tecnologia de Alimentos, Campinas, v. 28, n. 3, p. 718-726, 2008.

HIGBY, W. K. A simplified method for determination of some aspects of the carotenoid distribution in natural and carotene fortified orange juice. Journal of Food Science, Chicago, v. 27, n. 1, p. 42-49, 1962.

HOOVER, R. Composition, molecular structure, and physicochemical properties of tuber and root starches: a review. Carbohydrate Polymers, Oxford, v. 45, n. 3, p. 253-267, 2001.

KARIM, A. A.; TOON, L. C.; LEE, V. P.; ONG, W. Y.; FAZILAH, A.; NODA, T. Effects of phosphorus contents on the gelatinization and retrogradation of potato starch. Journal of Food Science, Chicago, v. 72, n. 2, p. C132-8, 2007.

KAUR, A; SINGH, N.; EZEKIEL, R.; GURAYA, H. $\mathrm{S}$. Physicochemical, thermal and pasting properties of starches separated from different potato cultivars grown at different locations. Food Chemistry, Saint Paul, v. 101, n. 2, p. 643-651, 2007a.

KAUR, L.; SINGH, J.; MCCARTHY, O. J.; SINGH, H. Physico-chemical, rheological and structural properties of fractionated potato starches. Journal of Food Engineering, Weinheim, v. 82, n. 3, p. 383-394, 2007 b.

KIM, Y.; WIESENBORN, D. P.; LORENZEN, J. H.; BERGLUND, P. Suitability of edible bean and potato starches for starch noodles. Cereal Chemistry, Saint Paul, v. 73, n. 3, p. 302-308, 1996.

LEACH, H. W.; MCCOWEN, L. D.; SCHOCH, T. J. Structure of the starch granule. I. Swelling and solubility patterns of various starches. Cereal Chemistry, Saint Paul, v. 36, n. 6, p. 534-544, 1959.

LEONEL, M.; SARMENTO, S. B. S.; CEREDA, M. P.; GUERREIRO, L. M. R. Extração e caracterização do amido de Biri (Canna edulis). Brazilian Journal of food technology, Campinas, v. 5, n. 77, p. 27-32, 2002.
LOMBARDI, J. A. Vitaceae. Lista de espécies da flora do Brasil. Rio de Janeiro: Jardim Botânico do Rio de Janeiro, 2013. Disponível em: $<$ http://floradobrasil.jbrj. gov.br/jabot/floradobrasil/FB248>. Acesso em: 01 jul. 2013.

MENDONÇA, H. A.; MOURA, G. M.; CUNHA, E. T. Avaliação de genótipos de mandioca em diferentes épocas de colheita no Estado do Acre. Pesquisa Agropecuária Brasileira, Brasília, v. 38, n. 6, p. 761-769, 2003.

MOORE, G. R. P.; CANTO, L. R.; AMANTE, E. G.; SOLDI, V. Cassava and corn starch in maltodextrin production. Química Nova, São Paulo, v. 28, n. 4, p. 596600, 2005.

NADIHA, M. Z. N.; FAZILAH, A.; BHAT, R.; KARIMB, A. A. Comparative susceptibilities of sago, potato and corn starches to alkali treatment. Food Chemistry, Saint Paul, v. 121, n. 4, p. 1053-1059, 2010.

NAKASON, C.; WOHMANG, T.; KAESAMAN, A.; KIATKAMJORNWONG, S. Preparation of cassava starch-graft-polyacrylamide superabsorbents and associated composites by reactive blending. Carbohydrate Polymers, Oxford, v. 81, n. 11, p. 348-357, 2010.

NARA, S.; KOMIYA, T. Studied on the relationship between water-saturated state and crystallinity by the diffraction method for moistened potato starch. Starch/ Stärke, Weinheim, v. 35, n. 12, p. 407-410, 1983.

OLUDARE, A. S.; MACDONALD, I. O. Variation in the physical, chemical and physico-functional properties of starches from selected cassava cultivars. New York Science Journal, New York, v. 3, n. 4, p. 48-53, 2010.

PARKER, R.; RING, S. G. Aspects of the physical chemistry of starch. Journal of Cereal Science, London, v. 34, n. 1, p. 1-17, 2001.

PERERA, C.; HOOVER, R. Influence of hydroxypropylation on retrogradation properties of native, defatted and heat-moisture treated potato starches. Food Chemistry, Saint Paul, v. 64, n. 3, p. 361-375, 1999.

RINCÓN, A. M.; PADILLA, F. C. Physicochemical properties of Venezuelan breadfruit (Artocarpus altilis) starch. Archivos Latinoamericanos de Nutrición, Caracas, v. 54, n. 4, p. 449-456, 2004.

SANDHU, K. S.; SINGH, N.; KAUR, M. Characteristics of the different corn types and their grain fractions: physicochemical, thermal, morphological, and rheological properties of starches. Journal of Food Engineering, Weinheim, v. 64, n. 1, p. 119-127, 2004. 
SINGH, N.; SINGH, J.; KAUR, L.; SODHI, N. S.; GILL, B. S. Morphological, thermal and rheological properties of starches from different botanical sources. Food Chemistry, Saint Paul, v. 81, n. 2, p. 219-231, 2003.

SRICHUWONG, S.; SUNARTI, T. C.; MISHIMA, T.; ISONO, N.; HISAMATSU, M. Starches from different botanical sources II: Contribution of starch structure to swelling and pasting properties. Carbohydrate Polymers, Oxford, v. 62, n. 1, p. 25-34, 2005.

TESTER, R. F.; KARKALAS, J.; QI, X. Starch composition, fine structure and architecture. Journal of Cereal Science, London, v. 39, n. 2, p. 51-165, 2004.

TESTER, R. F.; MORRISON, W. R. Swelling and gelatinization of starches 1. Effects of amylopectins, amyloses and lipids. Cereal Chemistry, Saint Paul, v. 67, n. 6, p. 551-557, 1990.

UTHUMPORN, U.; ZAIDUL, I. S. M.; KARIM, A. A. Hydrolysis of granular starch at sub-gelatinization temperature using a mixture of amylolytic enzymes. Food and Bioproducts Processing, Rugby, v. 88, n. 1, p. 47-54, 2010.

VILAPLANA, F.; HASJIM, J.; GILBERT, R. G. Amylose content in starches: Toward optimal definition and validating experimental methods. Carbohydrate Polymers, Oxford, v. 88, n. 1, p. 103-111, 2012.

WANG, P. X.; WU, X. L.; DONG-HUA, X.; KUN, X.; YING, T.; XI-BING, D.; WEN-BO, L. Preparation and characterization of cationic corn starch with a high degree of substitution in dioxane-THF-water media. Carbohydrate Research, Netherlands, v. 344, n. 7, p. 851-855, 2009.
YUAN, R. C.; THOMPSON, D. B.; BOYER, C. D. Fine structure of amylopectin in relation to gelatinization and retrogradation behavior of maize starches from three wx-containing genotypes in two inbred lines. Cereal Chemistry, Saint Paul, v. 70, n. 1, p. 81-89, 1993.

ZAIDUL, I. S. M.; NORULAINI, N. A. N.; OMAR, A. K. M.; YAMAUCHI, H.; NODA, T. RVA analysis of mixtures of wheat flour and potato, sweet potato, yam, and cassava starches. Carbohydrate Polymers, Oxford, v. 69, n. 4, p. 784-791, 2007.

ZHOU, X.; LIM, S. T. Pasting viscosity and in vitro digestibility of retrograded waxy and normal corn starch powders. Carbohydrate Polymers, Oxford, v. 87, n. 1, p. 235-239, 2012.

TAKIZAWA, F. F.; SILVA, G. O.; KONKEL, F. E.; DEMIATE, I. M. Characterization of tropical starches modified with potassium permanganate and lactic acid. Brazilian Archives of Biology and Technology, São Paulo, v. 47, n. 6, p. 921-931, 2004.

ZHANG, X.; TONG, Q. Y.; REN, F. Manuscript title: influence of glucose, sucrose and trehalose on the freezethaw stability of tapioca starch gels. Advance Journal of Food Science and Technology, Brooklyn, v. 4, n. 4, p. 225-230, 2012. 
